\title{
Film Dosing Unit
}

National Cancer Institute

\section{Source}

National Cancer Institute. Film Dosing Unit. NCI Thesaurus. Code C53499.

A dosing unit equal to the amount of active ing redient(s) contained in a film. 